\title{
Developmental Changes in the Rat Atriopeptin Hormonal System
}

\author{
Yuefang Wei, Charles P. Rodi," Mark L. Day," Roger C. Wiegand," Lawrence D. Needleman, \\ Barbara R. Cole, ${ }^{\ddagger}$ and Philip Needleman \\ The Edward Mallinckrodt Department of Pharmacology and Department of ${ }^{\ddagger}$ Pediatrics, Washington University School of Medicine, \\ St. Louis, Missouri 63110; *Biological Sciences Department, Monsanto Company, St. Louis, Missouri 63198
}

\begin{abstract}
We undertook a study of fetal synthesis, storage, and release of atriopeptin (AP). Plasma levels of both atriopeptin immunoreactivity $\left(\mathrm{AP}_{\mathrm{ir}}\right)$ and the $\mathrm{NH}_{2}$-terminal fragment of the prohormone immunoreactivity $\left(\mathrm{NTF}_{\text {ir }}\right)$ were very high in the fetus $(4$ and 20 times the maternal plasma, respectively). However, the atrial content of the AP was low, but surprisingly, ventricular content of AP was quite high (relative to the adult) in the fetus and fell postnatally. Atrial AP messenger RNA (mRNA) increased with postnatal age, whereas ventricular mRNA was extremely high in the fetus and fell rapidly after birth. High fetal plasma peptide levels may derive from the mother since infusion of exogenous atriopeptin 24 into the mother resulted in parallel increases in fetal and maternal peptide levels. Fetal plasma $\mathbf{A} \mathbf{P}_{\text {ir }}$ and $\mathrm{NTF}_{\text {ir }}$ levels partially reflect the markedly reduced total renal metabolic capacity compared with that of the adult. Plasma levels fell progressively after birth; whereas neonatal atrial content rose substantially. Plasma AP and NTF were simultaneously elevated in both the maternal and fetal circulation after vasopressin injection of the mother. The fetus can also respond to exogenous stimuli (vasopressin or indomethacin-presumably via ductal closure) and promptly release substantial amounts of peptide into its circulation. Thus, it appears that the AP hormonal system is functional during fetal life and responds avidly to increases in intracardiac pressure as does the mature animal.
\end{abstract}

\section{Introduction}

Atriopeptins (AP) ${ }^{1}$ are spasmolytic, natriuretic, and diuretic peptides found in adult mammalian cardiac atria $(1,2)$. The peptides have multiple effects, including inhibition of aldosterone, renin and vasopressin release, reduction in systemic blood pressure and enhancement of renal glomerular filtration rate (reviewed in references 3-6). AP release can be stimulated by volume expansion (6) or agents, including 1-desamino-arg ${ }^{8}$-vasopressin (dAVP), that elevate right atrial pressure (7). Plasma levels of AP are elevated in both experimental animals and humans in conditions of systemic hypertension $(8,9)$, pulmonary hypertension (10), cardiac arrhythmias $(11,12)$ and the syndrome of inappropriate antidiuretic hormone (13).

Address reprint requests to Dr. Philip Needleman, Department of Pharmacology, Washington University School of Medicine, 660 South Euclid, St. Louis, MO 63110.

Received for publication 29 September 1986

1. Abbreviations used in this paper: AP, atriopeptin, dAVP, 1-desamino$\mathrm{arg}^{8}$-vasopressin; ir, immunoreactivity; NTF, $\mathrm{NH}_{2}$-terminal fragment of the prohormone.

J. Clin. Invest.

(c) The American Society for Clinical Investigation, Inc.

0021-9738/87/05/1325/05 $\$ 1.00$

Volume 79, May 1987, 1325-1329
In the fetus or newborn, total body water is expanded, marked by a shift to a greater extracellular volume $(14,15)$. During the first few days after birth the neonate generally displays an exaggerated natriuresis and diuresis, resulting in a decrease of total body water and a lowering of extracellular volume toward the adult level (16). Furthermore, patterns of blood flow and vascular resistance alter dramatically with birth (17). To determine the association of AP with blood flow and volume changes associated with birth, we evaluated AP plasma and cardiac levels and determined the capacity for peptide release during late gestational and early neonatal periods in the rat.

\section{Methods}

Plasma and cardiac peptide levels. Pregnant Sprague-Dawley rats had pregnancy interrupted at gestational day 20 (E-20) or were allowed to deliver, and their pups were studied on days of life $3,5,7,9,11$, and 21. For evaluation of plasma AP levels and cardiac stores, the fetus or neonate was decapitated. Blood was collected in $0.11 \mathrm{M}$ sodium citrate $(1: 10, \mathrm{vol} / \mathrm{vol})$ and centrifuged at $10,000 \mathrm{~g}$ for $1 \mathrm{~min}$. The cardiac atria and ventricles were separated, homogenized with $1 \mathrm{M}$ acetic acid, boiled for $10 \mathrm{~min}$, and then centrifuged for $5 \mathrm{~min}$ at $10,000 \mathrm{~g}$. Both the supernatants and plasma were stored at $-70^{\circ} \mathrm{C}$ until assay.

Maternal to fetal AP transfer. To determine whether AP crosses the placenta, atriopeptin 24 (AP-24) was infused into the mother, and simultaneous blood samples were collected from the mother and fetuses. The 20-d pregnant rats were anesthetized with chloral hydrate $(350 \mathrm{mg} /$ $\mathrm{kg}$ i.p.). The jugular vein was cannulated for AP-24 infusion ( $300 \mathrm{ng} /$ min for $30 \mathrm{~min}$ ), and the carotid artery was cannulated for blood collection. A midline incision was made in the lower abdomen to expose the uterus. At specific time points one fetus was removed and decapitated and blood was collected.

Maternal and fetal endogenous AP release. dAVP (Peninsula Laboratories, Inc., Belmont, CA) was injected i.v. into anesthetized 20-d pregnant animals ( $1 \mu \mathrm{g}$ bolus) or i.p. into the fetus directly through the uterine wall $(25$ or $50 \mu \mathrm{g} / \mathrm{kg})$. At time intervals of $2,5,15$, and $30 \mathrm{~min}$ after injection, blood was collected from the mother. One fetus was utilized for each blood sample at the same time points.

Indomethacin is known to precipitate closure of the ductus arteriosus $(18,19)$. To determine the effect ductal closure on AP release in the E20 fetus, pregnant animals were given indomethacin $(5 \mathrm{mg} / \mathrm{kg}$, Sigma Chemical Co., St. Louis, MO, dissolved in Tris- $\mathrm{HCl}$ buffer, pH 8, i.p.) three times daily on gestational days 18 and 19. On day 20 the fetuses were aborted, and plasma and cardiac extracts were prepared and stored for assay. In further studies, aspirin (Sigma Chemical Co.) was suspended in $5 \%$ gelatin and administered orally to the pregnant rats $(100 \mathrm{mg} / \mathrm{kg})$ three times daily on days 18 and 19 . Blood was collected on the following day as in the indomethacin studies. The effect of indomethacin on AP release in the neonate was also studied by injecting indomethacin $(5 \mathrm{mg} /$ $\mathrm{kg}$ i.p. three times daily) on postnatal day of life 1 and killing on day 2, or neonates were injected on days 3 and 4 after birth and killed on day 5 .

Renal AP metabolic rate. In order to determine the catabolism of AP-24 by the kidney, slices from adult kidneys were removed from anesthetized rats and homogenized in phosphate-buffered saline $(\mathrm{pH} 7.4)$ with $0.25 \%$ bovine plasma albumin to a final dilution of $1: 800$. For the fetal rats (E-20), four kidneys were combined per study; for neonatal 
rats, (day 3) two kidneys were pooled. For each sample, $990 \mu$ l of diluted kidney in buffer was preincubated at $37^{\circ} \mathrm{C}$ for $5 \mathrm{~min}$. Then $10 \mu \mathrm{l}$ of atriopeptin 28 (AP-28) (final concentration 4, 40, $400 \mathrm{nM}$ ) was added, and incubated with the homogenate for $10 \mathrm{~min}$. The reaction proceeded at a linear rate for $>10 \mathrm{~min}$, and was stopped by rapid dilution by placing an aliquot of the sample in chilled radioimmunoassay (RIA) buffer and proceeding with RIA. The residual AP- 28 was measured and subtracted from the original amount to determine the velocity of the reaction.

AP messenger RNA characterization. Atrial and ventricular RNA were prepared as described previously (Day et al., manuscript submitted for publication) and quantitated by $A_{260}$. RNA was displayed by electrophoresis through gels of $1.5 \%$ agarose in $10 \mathrm{mM} \mathrm{NaPO}_{4}, 3.7 \%$ formaldehyde ( $\mathrm{pH} 7.5$ ). The accuracy of the relative quantitation was checked by staining the gels with ethidium bromide before blotting the RNA onto nitrocellulose filters. The filters were probed with a purified 760-basepair (bp) AP complementary DNA fragment (Day and Wiegand, unpublished data) labeled to $5 \times 10^{7} \mathrm{cpm} / \mu \mathrm{g}$ with ${ }^{32} \mathrm{P}$ by nick translation, washed twice for $15 \mathrm{~min}$ in $0.1 \times$ standard saline citrate (SSC) at $20^{\circ} \mathrm{C}$ and twice for $15 \mathrm{~min}$ in $0.01 \times \mathrm{SSC}$ at $45^{\circ} \mathrm{C}$, and exposed to Kodak XAR film for $16 \mathrm{~h}$ as described previously (Day et al., manuscript submitted for publication).

$R I A$. The specific RIA for AP (20) and for the $\mathrm{NH}_{2}$-terminal fragment of the prohormone (NTF) (21) have been described previously. Briefly, for the AP RIA, the samples were incubated with $10,000 \mathrm{cpm} /$ tube $^{125} \mathrm{I}$ AP-24 and a 1:300,000 final dilution of guinea pig antiserum generated against synthetic rat AP-24. The cross-reactivity between AP-24 and AP28 is $100 \%$ with this guinea pig antisera. Antibody-bound radioligand was incubated with a 1:10,000 final dilution of anti-guinea pig IgG antiserum (Linco Research Inc., Eureka, MO) at $4^{\circ} \mathrm{C}$ overnight. After centrifugation at $3,000 \mathrm{~g}$ for $30 \mathrm{~min}$, the pellet was washed with $0.25 \%$ bovine plasma albumin in $10 \mathrm{mM}$ sodium azide, and radioactivity was counted in a Micromedic Apex gamma counter (Micromedic Systems, Inc., Horsham, PA).

\section{Results}

Fetal and neonatal plasma and tissue peptide levels. Baseline fetal and neonatal immunoreactivity (ir) levels of both $\mathbf{A P}_{\text {ir }}$ and $\mathrm{NTF}_{\text {ir }}$ were remarkably different from those of the mother. Fig. 1 shows that the $A P_{i r}$ of the fetus was $2.7 \pm 0.18 \mathrm{ng} / \mathrm{ml}$ and the $\mathrm{NTF}_{\text {ir }}$ value was $60 \pm 12 \mathrm{ng} / \mathrm{ml}$. In contrast, the maternal values were $0.46 \pm 0.05 \mathrm{ng} / \mathrm{ml}$ for $\mathrm{AP}_{\mathrm{ir}}$ and $4.3 \pm 0.9 \mathrm{ng} / \mathrm{ml}$ for $\mathrm{NTF}_{\mathrm{ir}}$. By $3 \mathrm{~d}$ of postnatal age, both levels had fallen with the $\mathrm{NTF}_{\mathrm{ir}}$ level falling markedly between 3 and $5 \mathrm{~d}$ (Fig. 1).

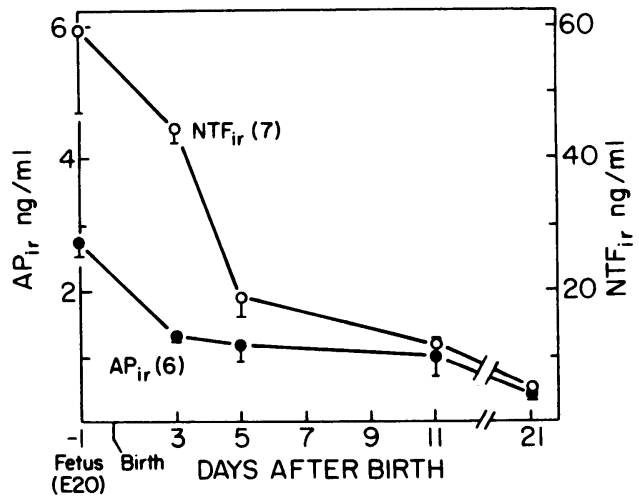

Figure 1. Fetal and neonatal plasma levels of atriopeptins. The values are reported as the mean \pm SEM from six animals of each group in AP immunoreactivity $\left(\mathrm{AP}_{\mathrm{ir}}\right)$ and from seven animals of each group in NTF immunoreactivity $\left(\right.$ NTF $\left._{\text {ir }}\right)$.
The higher plasma levels of AP in the fetus and their longer circulation time might result from slower removal of the peptide. Comparison of the velocity of AP disappearance when incubated with renal homogenates showed no major differences on a per milligram of tissue basis among adult, fetal, and 3-d-old animals. The removal, therefore, was dependent entirely on the total mass of renal tissue which increased with age. With the highest concentration of AP used ( $400 \mathrm{nM}$ to approximate maximum rates), removal of AP by the total adult kidney was $205.9 \pm 3.8 \mathrm{nmol}$ per $10 \mathrm{~min}$; by 3-d-old kidney, 12.4 \pm 1.3 ; and by fetal kidney, $5.5 \pm 0.3(n=5)$.

Comparison of atrial and ventricular content of AP in the fetal, neonatal, and adult rats was surprising (Fig. 2). The ventricle of the fetus contained $24.8 \pm 1.9 \mathrm{ng} / \mathrm{mg}$ protein, with this value falling only slightly by $3 \mathrm{~d}$ of postnatal age. By $14 \mathrm{~d}$, the level had diminished greatly, and by $21 \mathrm{~d}$ was still measurable but very low at $1.2 \pm 0.1 \mathrm{ng} / \mathrm{mg}$ protein. Atrial content was considerably higher than ventricular levels at all ages but showed the reverse maturational pattern. Levels of $\mathrm{AP}_{\mathrm{ir}}$ in the fetus were $548 \pm 43 \mathrm{ng} / \mathrm{mg}$ protein, rising to a peak of $2880 \pm 216 \mathrm{ng} / \mathrm{mg}$ protein at $3 \mathrm{wk}$.

$A P M R N A$ levels in neonatal atria and ventricles. The developmental regulation of the AP mRNA was, if anything, more striking than the differences observed in the stored peptide or circulating peptide levels. As shown in Fig. $3 A$, AP mRNA levels increase in atria with the same time course and to about the same extent as the observed increase in the stored peptide levels. Ventricular mRNA levels are extremely high in the neonate, approaching the levels seen in atria from adults. These levels fall rapidly over the first 2 wk after birth (Fig. $3 \mathrm{~B}$ ). The ratio of stored $A P_{\text {ir }}$ to $\mathrm{mRNA}$ is thus substantially higher in the adult atrium than it is in the neonatal ventricle, suggesting posttranscriptional control of the stored $\mathrm{AP}_{\text {ir }}$ levels. This control could occur at the level of translation, but is more likely to result from altered processing or secretion of the peptide.

Placental transport of atrial peptide. Maternal infusion of AP-24 resulted in elevated fetal AP levels (Fig. 4). Upon initiation of the infusion, both fetal and maternal levels of $\mathrm{AP}_{\mathrm{ir}}$ rose rapidly. However, when the infusion was terminated, the maternal level fell to baseline within $5 \mathrm{~min}$ while the fetal level plateaued, falling only after 90-120 min. When control studies were done by infusing a comparable volume of saline into the mother, no changes in $\mathrm{AP}_{\mathrm{ir}}$ were detected in either the mother or the fetus.

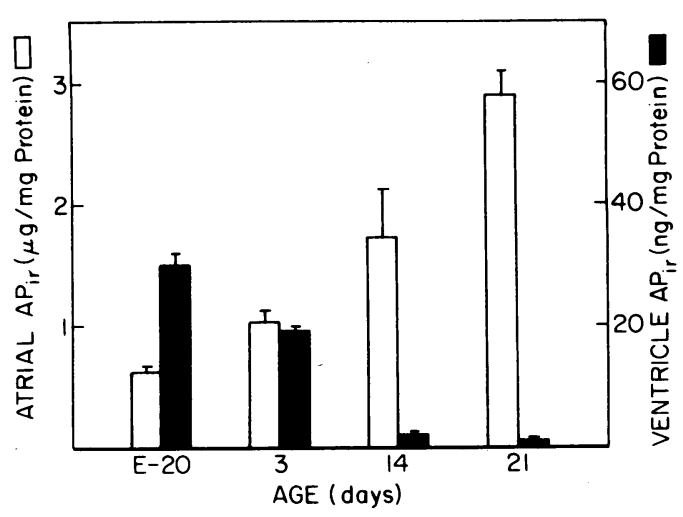

Figure 2. Fetal and neonatal cardiac content of atriopeptins. The open bars represent the atrial $\operatorname{AP}_{\text {ir }}(n=7)$ and the closed bars represent the ventricular $\mathrm{AP}_{\mathrm{ir}}(n=10)$. 
A

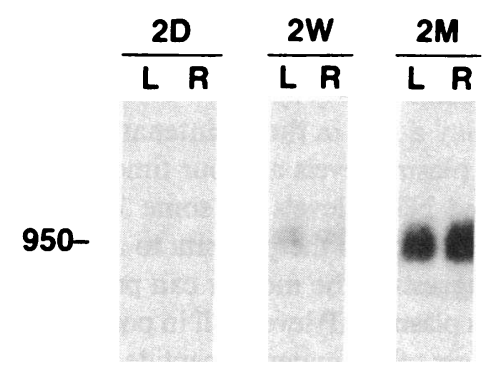

B
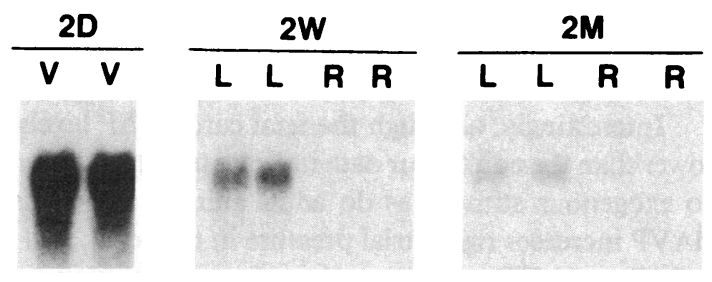

Figure 3. AP and mRNA in atria and ventricles during development. $(A)$ Northern blot of RNA from left and right atria of various age animals. The samples ( $1 \mu \mathrm{g}$ total RNA per lane) were from left $(L)$ and right $(R)$ atria from animals that were $2 \mathrm{~d}(2 D), 2 \mathrm{wk}(2 W)$, or $2 \mathrm{mo}$ $(2 M)$ old. Samples were prepared, blotted, and probed as described in Methods. $(B)$ Northern blot of RNA from left and right ventricles of various age animals. The samples ( $10 \mu \mathrm{g}$ total RNA per lane) were from the lower half of the whole ventricle $(V)$ or left $(L)$ or right $(R)$ ventricular walls from animals that were $2 \mathrm{~d}(2 D), 2 \mathrm{wk}(2 W)$, or 2 mo $(2 M)$ old. Samples were prepared, blotted, and probed as described in Methods.

Because it is known that dAVP stimulates the release of both AP-28 and its NTF (but no intact prohormone is released) into the circulation of adult rats (9), experiments were undertaken to discern whether this stimulus would be effective in the already volume-expanded pregnant animal and whether peptide levels in the fetus would be altered. Fig. 5 shows that $1 \mu \mathrm{g}$ of dAVP given to the mother prompted a rise in both $A P_{i r}$ and $N T F_{i r}$ in both maternal and fetal animals. The $\mathrm{NTF}_{\text {ir }}$ level remained high in the mother for at least $30 \mathrm{~min}$ after injection, whereas the $\mathrm{AP}_{\text {ir }}$ level fell to baseline by $30 \mathrm{~min}$. As seen with maternal AP

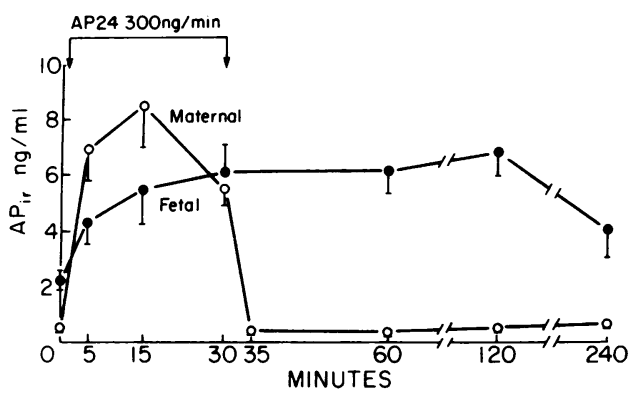

Figure 4. Maternal and fetal atriopeptin levels produced by infusion of exogenous AP-24 into the mother. Values represent the mean \pm SEM for five mothers and 10 fetuses of each group.

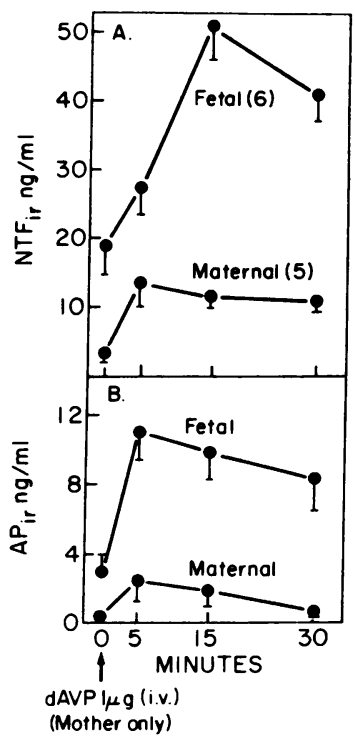

Figure 5. Effect of maternal dAVP stimulation on plasma levels of AP in mother and fetus. Values represent the mean \pm SEM for five mothers and six fetuses of each group. infusion, however, the fetal levels of both $\mathrm{AP}_{\mathrm{ir}}$ and $\mathrm{NTF}_{\mathrm{ir}}$ remained high during that $30 \mathrm{~min}$.

Fetal $A P$ release. The rise in fetal atrial peptide levels after a bolus injection of dAVP probably reflects the placental transfer of both the AP-28 and the remaining high molecular weight NTF. However, some of the fetal response might derive from the effects of any dAVP that crossed the placenta from the mother to the fetus. The uterus was exposed in pregnant rats, and an intraperitoneal injection of dAVP to the fetal animal through the uterine wall produced a striking elevation in $\mathbf{A P}_{\mathrm{ir}}$ in the fetus (Fig. 6). The lower dose of $25 \mu \mathrm{g} / \mathrm{kg}$ (i.p.) given to the fetus resulted in no change in maternal levels, but the higher dose of $50 \mu \mathrm{g} / \mathrm{kg}$ to the $1-2-\mathrm{g}$ fetus doubled the maternal $\mathrm{AP}_{\mathrm{ir}}$ value. In control fetal animals, a similar volume of saline injected i.p. led to no change in fetal or maternal $\mathbf{A P}_{\text {ir }}$ levels.

The patent ductus arteriosus allows blood to go from the pulmonary artery where high pulmonary vascular resistance impedes flow to the systemic circulation where vascular resistance is less. Ductal patency is largely maintained by endogenous vascular synthesis of the vasodilator prostaglandins (prostaglandin $\mathrm{E}_{2}$ and prostacyclin). Agents, such as indomethacin or aspirin,

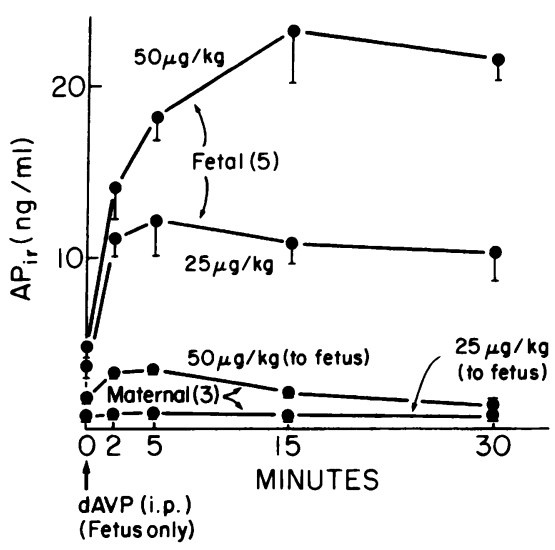

Figure 6. Effect of fetal dAVP stimulation on plasma levels of AP in mother and fetus. Values represent the mean \pm SEM for three mothers and five fetuses of each group. 
that inhibit prostaglandin biosynthesis have been demonstrated in many species to close the ductus. Fig. 7 illustrates the changes in $\mathrm{AP}_{\mathrm{ir}}$ effected by giving the pregnant animal indomethacin and presumably closing the ductus. Administration of indomethacin produced a striking increase in fetal plasma $\mathbf{A P}_{\text {ir }}$ compared with a control group which received the vehicle. Simultaneously, there was a significant decrement in the AP concentration of the right atrium. No significant differences were demonstrable in the left atrium, the combined ventricles, nor in the maternal plasma $\mathrm{AP}_{\mathrm{ir}}$. Furthermore, a 2-d-old neonate (at a time when the ductal closure would have already naturally occurred), which had received indomethacin on day 1 and was killed on day 2 , had plasma $\mathrm{AP}_{\text {ir }}$ levels (indomethacin $4.05 \pm 0.53$ $\mathrm{ng} / \mathrm{ml})$ no different from the control animals $(3.17 \pm 0.70 \mathrm{ng} /$ $\mathrm{ml}$ ). Indomethacin treatment of 3- and 4-d-old neonates (sacrificed on day 5) were also not different from controls (indomethacin $1.47 \pm 0.32 \mathrm{ng} / \mathrm{ml}$ vs. control $0.97 \pm 0.18 \mathrm{ng} / \mathrm{ml}$. Treatment of pregnant animals with aspirin (another cyclooxygenase inhibitor) also produced an elevation in fetal plasma $\mathrm{AP}_{\mathrm{ir}}$. After $1 \mathrm{~d}$ of treatment, the $\mathrm{AP}_{\mathrm{ir}}$ level was $4.2 \pm 0.76 \mathrm{ng} / \mathrm{ml}(n=3)$ rising to $10.2 \pm 2.3 \mathrm{ng} / \mathrm{ml}(n=6)$ with $2 \mathrm{~d}$ of treatment and $11.3 \pm 1.9$ $\mathrm{ng} / \mathrm{ml}(n=8)$ with $3 \mathrm{~d}$. The $\mathrm{AP}_{\text {ir }}$ level in the mother did not change during this time.

\section{Discussion}

During fetal life, vascular resistances are variable. Blood coming from the placenta goes through the ductus venosus to the heart where a portion goes from the right atrium through the foramen ovale into the left atrium. The remainder of the blood goes into the right ventricle and into the pulmonary artery. However, pulmonary vascular resistances are high during fetal life, and as a result, the blood entering the pulmonary artery passes through the patent ductus arteriosus and enters the systemic circuit via the aorta. The blood that has come across the foramen ovale plus the blood that has come through the ductus arteriosus then is delivered to the systemic circuit. $65 \%$ of this blood goes back to the placenta while the other $35 \%$ is delivered to the fetal body (17). Because of the large percentage of return to the placenta for oxygenation, the systemic blood pressure in the fetus and vascular resistances are relatively low. After birth, the blood flow pattern changes and the vascular resistances are altered. Once the neonate becomes an air breather and the blood becomes more oxygenated, pulmonary vascular resistances fall and the blood can travel throughout the pulmonary circuit. With increased oxygen tension and decreased prostaglandins, the ductus

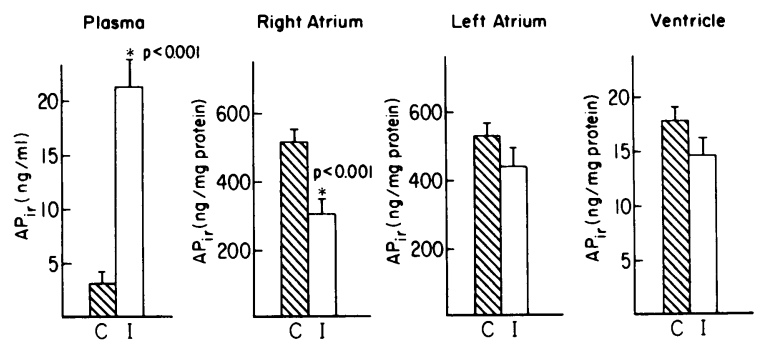

Figure 7. Effect of maternal indomethacin administration on plasma and cardiac levels of AP in fetus. The open bars represent the indomethacin treated group (eight fetuses of each group) and the hatched bars represent the control group (10 fetuses of each group). arteriosus closes. With the removal of the placenta from the systemic circuit, systemic vascular resistances rise, and blood pressure rises somewhat (17).

AP may play a role in the maintenance of these blood flow patterns. $\mathrm{AP}_{\text {ir }}$ plasma levels are four times higher than those in the mother and $\mathrm{NTF}_{\text {ir }}$ levels are some 10 times higher. Atrial peptides appear to cross the placenta to accumulate in the fetal circulation, suggesting the mother can provide a major portion of fetal AP. As plasma AP levels fall in postnatal life, presumably reflecting the loss of the maternal peptide, there is a concomitant rapid elevation in neonatal atrial AP content and synthetic capacity. It is also noteworthy that the fetal ventricles contain considerable AP. Once the fetus is delivered and the pulmonary circuit opens, ventricular peptide and mRNA content progressively falls. Adult ventricular AP synthesis and content are very low, but we recently demonstrated that left ventricular hypertrophy induced by aorta banding rapidly results in the induction of AP mRNA and peptide levels in the left ventricle (Day et al., manuscript submitted for publication).

Interestingly, although the fetal cardiac AP levels are much lower than the adults, our data indicate that the fetus can respond to exogenous stimuli, as do adult animals. Administration of dAVP increases right atrial pressure in the adult, and stimulates AP (7) and NTF release in a dose-dependent manner. This phenomenon is also demonstrated very clearly by the administration of dAVP to the mothers, showing a prompt response in release of AP with an elevation in maternal levels. Similarly, dAVP administered to the fetus causes a prompt rise in fetal AP levels. The experiments observing the effect of indomethacin and aspirin would suggest that the fetal cardiac AP system does respond to changes in intracardiac pressure. If the ductus arteriosus were to close prior to the time of birth, intracardiac pressure (both ventricular and atrial) would rise sharply, and the release of AP would be anticipated. In our studies, indomethacin and aspirin administration to the mother resulted in a pronounced increase in circulating plasma AP levels in the fetus, whereas maternal levels did not change. In contrast, when indomethacin was given after the time when the ductus had closed after birth, there was no such effect.

Whether fetal AP are involved in the regulation of fetal body fluids is unknown. However, after birth when there is a sudden change in blood flow and vascular resistance, the circulating high level of AP may participate in the postnatal diuresis and natriuresis that occurs. Furthermore, the fact that the placenta has been found to be a rich source of AP receptors (22) suggests a possible role in regulation of placental blood flow or fluid exchange. It appears, then, that the AP system develops during fetal life, and that AP can cross the placenta from the mother to the fetus and that release of AP is stimulated by an increase in intracardiac pressures much as is demonstrable in the mature animal. The regulation of AP synthesis and its relation to physiological changes in blood flow and volume regulation in development present challenging problems for resolution.

\section{References}

1. de Bold, A. J., H. B. Borenstein, A. T. Veress, and H. Sonnenberg. 1981. A rapid and potent natriuretic response to intravenous injection of atrial myocardial extract in rats. Life Sci. 28:89-94.

2. Currie, M. G., D. M. Geller, B. R. Cole, J. G. Boylan, W. YuSheng, S. W. Holmberg, and P. Needleman. 1983. Bioactive cardiac substances: 
potent vasorelaxant activity in mammalian atria. Science (Wash. DC). 221:71-73.

3. Needleman, P., S. P. Adams, B. R. Cole, M. G. Currie, D. M. Geller, M. L. Michener, C. B. Saper, D. Schwartz, and D. Standaert. 1985. Atriopeptins as cardiac hormones. Hypertension (Dallas). 7:469482.

4. Maack, T., M. J. F. Camargo, H. D. Kleinert, J. H. Laragh, and S. A. Atlas. 1985. Atrial natriuretic factor: structure and functional properties. Kidney Int. 27:607-615.

5. Ballermann, B. J., and B. M. Brenner. 1985. Biologically active atrial peptides. J. Clin. Invest. 76:2041-2048.

6. Needleman, P., and J. E. Greenwald. 1986. Atriopeptin: a cardiac hormone intimately involved in fluid-electrolyte and blood pressure homeostasis. N. Engl. J. Med. 314:828-834.

7. Manning, P. T., D. Schwartz, N. C. Katsube, S. W. Holmberg, and P. Needleman. 1985. Vasopressin-stimulated release of atriopeptin: endocrine antagonist in fluid homeostasis. Science (Wash. DC). 229: 395-397.

8. Imada, T., R. Takayanagi, and T. Inagami. 1985. Changes in the content of atrial natriuretic factor with the progression of hypertension in spontaneously hypertensive rats. Biochem. Biophys. Res. Commun. 133:759-765.

9. Sagnella, G. A., A. C. Shore, N. D. Markandu, and G. A. MacGregor. 1986. Raised circulating levels of atrial natriuretic peptides in essential hypertension. Lancet. $i: 179-181$.

10. McKenzie, J. C., I. Tanaka, T. Inagami, K. S. Misono, and R. M. Klein. 1986. Alterations in atrial and plasma atrial natriuretic factor (ANF) content during development of hypoxia-induced pulmonary hypertension in the rat. Proc. Soc. Exp. Biol. Med. 181:459-463.

11. Schiffrin, E. L., J. Gutkowska, O. Kuchel, M. Cantin, and J. Genest. 1985. Plasma concentration of atrial natriuretic factor in a patient with paroxysmal atrial tachycardia. $N$. Engl. J. Med. 312:1196-1197.

12. Yamaji, T., M. Ishibashi, H. Nakaoka, K. Imataka, M. Amano, and J. Fujii. 1985. Possible role for atrial natriuretic peptide in polyuria associated with paroxysmal atrial arrhythmias. Lancet $i: 1211$.

13. Cogan, E., M. F. Debieve, I. Philipart, T. Pepersack, and M. Abramow. 1986. High plasma levels of atrial natriuretic factor in SIADH. N. Engl. J. Med. 314:1258-1259.

14. Oh, W., L. Steward, G. S. Baens, and J. Metcoff. 1965. Body composition and renal adaptation in the newborn rat. Biol. Neonat. 8: 65-80.

15. Friis-Hansen, B. 1957. Changes in body water compartments during growth. Acta Paediatr. Suppl. 46:110.

16. Kagan, B. M., V. Stanincova, N. S. Felix, J. Hodgman, and D. Kalman. 1972. Body composition of premature infants: relation to nutrition. Am. J. Clin. Nutr. 25:1153-1164.

17. Kaplan, S. 1979. Fetal and neonatal circulation. In Nelson Textbook of Pediatrics. V. C. Vaughan III, R. J. McKay, and R. E. Behrman, editors. W. B. Saunders Co., Philadelphia. 1279-1281.

18. Clyman, R. I., F. Mauray, M. A. Heymann, and A. M. Rudolph. 1978. Ductus arteriosus: developmental response to oxygen and indomethacin. Prostaglandins. 15:993-998.

19. Coceani, F., and P. M. Olley. 1980. Role of prostaglandins, prostacyclin, and thromboxanes in the control of prenatal patency and postnatal closure of the ductus arteriosus. Semin. Perinatol. (NY). 4:109113.

20. Schwartz, D., D. M. Geller, P. T. Manning, N. R. Siegel, K. F. Fok, C. E. Smith, and P. Needleman. 1985. Ser-leu-arg-arg-atriopeptin III: the major circulating form of atrial peptide. Science (Wash. DC). 229:397-400.

21. Michener, M. L., J. K. Gierse, R. Seetharam, K. F. Fok, and P. Needleman. 1986. Proteolytic processing of atriopeptin prohormone. Mol. Pharmacol. 30:552-557.

22. Sen, I. 1986. Identification and solubilization of atrial natriuretic factor receptors in human placenta. Biochem. Biophys. Res. Commun. 135:480-486. 